\title{
Smart Integrated Payment System for Public Transportation in Jakarta
}

\author{
Harco Leslie Hendric Spits Warnars ${ }^{\star 1}$, Yulia Lanita ${ }^{2}$, Andhika Prasetyo ${ }^{3}$, Richard \\ Randriatoamanana ${ }^{4}$ \\ ${ }^{1}$ Doctor of Computer Science, Bina Nusantara University, Jakarta 11480, Indonesia \\ ${ }^{2,3}$ School of Information Systems, Bina Nusantara University, Jakarta 11480, Indonesia \\ ${ }^{4}$ Institut de Calcul Intensif, Ecole Centrale de Nantes, 44321 Nantes Cedex 3, France \\ *Corresponding author, e-mail: Spits.hendric@binus.ac.id ${ }^{1}$, Yulia.lanita@binus.ac.id ${ }^{2}$, \\ Andhika.prasetyo@binus.ac.id ${ }^{3}$, richard.randriatoamanana@ec-nantes.fr ${ }^{4}$
}

\begin{abstract}
Jakarta has many types of public transportation such as Kereta Rel Listrik (KRL), Transjakarta, taxi, angkot, metromini, mikrolet, bajaj, ojek, etc. But, there are some problems that happen in public transportation where the people don't want to use public transportation and choose to use private transportation that cause more traffic in Jakarta. The problems of public transportation are in the facility which is still inappropriate, unclear information, uncomfortable, bad accessibility of public transportation which take more time to reach the destination, more complicated than taking the private transportation, and about the society, people don't want to be labeled as low-class level. This paper is representing how to make the better system for public transportation in Jakarta with smart integrated payment system. Aim of this system is to encourage people to use public transportation rather than private transportation. The payment system that proposed are using smartphone application by scanning the QR Code or using smart card. User can easily pay through application by scanning $Q R$ code to pay the public transportation. The proposed of this smart integrated payment system will have opportunity as profit when collaborate with business when they can advertise their business and get customer from our user.
\end{abstract}

Keywords: Jakarta public transportation, Jakarta integrated payment, electronic wallet, smart integrated payment system

\section{Introduction}

Jakarta, the capital city of Republic of Indonesia is located on the northern coast of West Java. Jakarta is a huge province that become home for 9 million people. But the number increases with 2 million people during the day with the commuters, because they want to work in the city, then flock out again in the evening. This city also famous with the traffic jam especially during peak hours or when we travelling into business districts [1]. Government of Jakarta usually recommend us to use the public transportation in Jakarta, so it will make us spared from the traffic jam (when we use Transjakarta), then will decrease the traffic jam in Jakarta, so not every single people in Jakarta use their own transportation [24], [27].

There are many types of public transportation in Jakarta that we can take to go to the place that we want to go. The first type is Kereta Rel Listrik (KRL), this is the train that we can take from one station to another station in Jakarta, even we can travel with KRL among these cities such as Bogor, Depok, Tangerang, Bekasi, etc. The next type of public transportation is Bus, there are many bus in Jakarta such as Transjakarta, this transportation should be taken from one stop to another stop and there is a busway which is the road that exclusive for Transjakarta. There is also Taxi, Angkot, Metromini, Mikrolet, Bajaj, and Ojek that we can take to anywhere we want [2].

Even there are so many public transportations in Jakarta, the Jakarta citizens prefer to use their own transportation rather than the public transportation. Recorded from Dinas Perhubungan DKI Jakarta there are 7,5 million units of vehicle that traverse in Jakarta every day. Most of them approximately $98.6 \%$ which is 7,4 million units is private vehicle, then the rest $1,4 \%$ is public transportation. The reason is simply because there is no guarantee that people can on time get to their destination. There is still many of public transportation still not discipline, 
stop anywhere they want and take a long time to stop, the time is depending on the driver. People don't know what time the transportation will come. Besides that, the public transportation still not convenience to most of people, they should stay crowded with others, the cleanliness of the transportation and the safety [3]. Moreover, there are some problem that happen in the public where the people don't want to use public transportation. They prefer to use personal or private transportation rather than public transportation. That's what makes traffic jam [25].

By the statement above, we will propose a system for public transportation payment, that encourage the people to use the public transportation using incentive, by adding some points every time people use and they can redeem the points for a discount, promo, etc. Make the user easily know the information about the public transportation[26]. Like the route and the location of the public transportation, an approximate time for the public transportation will come, also the traffic condition there until the end of your route. With this system, we hope that will increase the users of public transportation, also the convenience for using the public transportation[28].

\section{Current Situation of Traffic in Indonesia}

Jakarta is the center of governmental and the center of commercial activity, this fact attracting many newcomers to come and live in Jakarta. Even the availability of land for housing in Jakarta is very limited, it makes the high prices of houses in Jakarta. Because of that, people are willing to reside in surrounding Jakarta. This is impact to the increasing the number of residents in Tangerang, Bekasi and Bogor area. As shown in Figure 1, the population of Jakarta increased to 9,6 million people in 2010, that means increase $15 \%$ since 2000 , meanwhile in Bogor increased 42\%, Tangerang City increased 34\% and Bekasi Increased 56\%. [4].

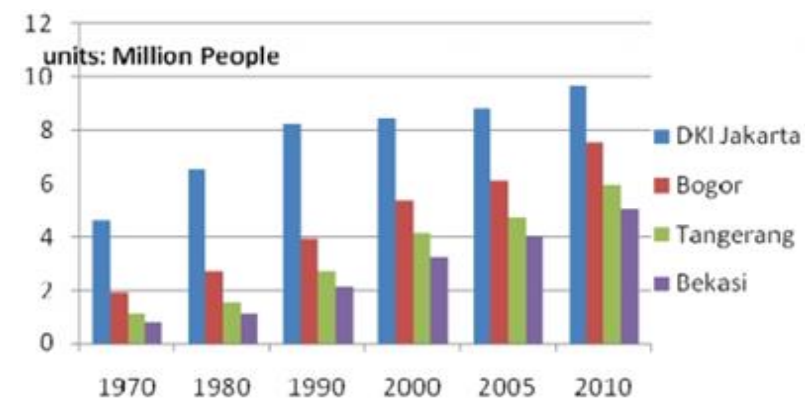

Figure 1. Number of population increased in Jakarta, Bogor, Tangerang City and Bekasi [4]

Most of the people who lives in the surrounding Jakarta, do their daily activities in Jakarta, like working, studying, shopping, traveling, etc. This situation makes to growing number of commutes who travel roundtrip to and from Jakarta. From data in Figure 2, in 2010 showed the commuter increase for $40 \%$ from Tangerang (West of Jakarta), $60 \%$ from Bekasi (East of Jakarta) and 40\% from Depok and Bogor (South of Jakarta) [4].

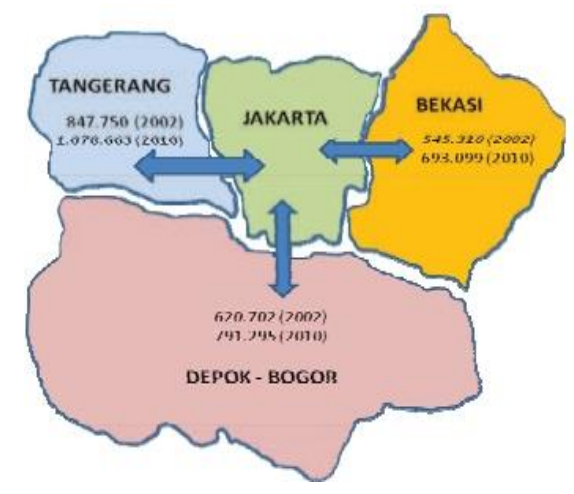

Figure 2. The commuter travel pattern to Jakarta from surrounding Jakarta [4] 
The enhancement human population also increased the number of vehicle in Jakarta. But the increasing of the vehicle in Jakarta is not supported by the adequate capacity of roads, that causes the traffic density in Jakarta. The length of roads in Jakarta only 163.780 meters or area of $2.811 .474 \mathrm{~m}^{2}$. On the other hand, the number of vehicles which travelling in Jakarta are $1.412 \mathrm{unit} / \mathrm{km}^{2}$ and moreover the facilities of public transportation are not comfortable.

Table 1 show the recorded number of motor vehicles in Jakarta according to the DKI Jakarta Police Office that consistently increasing each year. It can be seen from the number of vehicles registered annually. In 2011 where total vehicle in Jakarta is recorded more than 13 million. Motorcycle is still dominant by number more than 9 million, followed by passenger cars (2.5 million), and the rests are trucks and buses (0.9 million) [5].

\begin{tabular}{|c|c|c|c|c|c|}
\hline Year & Motorcycle & Passenger Cars & Trucks & Buses & Total \\
\hline 2001 & $1,813,136$ & $1,130,496$ & 347,433 & 253,648 & $3,544,713$ \\
\hline 2002 & $2,257,194$ & $1,195,871$ & 366,332 & 254,849 & $4,074,135$ \\
\hline 2003 & $3,316,900$ & $1,529,824$ & 464,748 & 315,652 & $5,627,124$ \\
\hline 2004 & $3,940,700$ & $1,645,306$ & 488,517 & 316,393 & $6,390,919$ \\
\hline 2005 & $4,647,435$ & $1,766,801$ & 499,581 & 316,502 & $7,230,319$ \\
\hline 2006 & $5,310,068$ & $1,835,653$ & 504,727 & 317,050 & $7,967,498$ \\
\hline 2007 & $5,974,173$ & $1,916,469$ & 518,991 & 318,332 & $8,727,965$ \\
\hline 2008 & $6,765,723$ & $2,034,943$ & 538,731 & 308,528 & $9,647,925$ \\
\hline 2009 & $7,518,098$ & $3,116,282$ & 550,924 & 309,385 & $10,494,689$ \\
\hline 2010 & $8,764,130$ & $2,334,883$ & 565,727 & 332,779 & $11,997,519$ \\
\hline 2011 & $9,861,451$ & $2,541,351$ & 581,290 & 363,710 & $13,347,802$ \\
\hline
\end{tabular}

Table 1 shows the total number of vehicle in DKI Jakarta are increased rapidly every year and most of the vehicle is Private Transportation such as Motorcycle and Car. The increase of Private Transportation is more dominating rather than Massive Transportation (Busses and Truck). According to JUTPI (JABODETABEK Urban Transportation Policy Integration) Commuter Survey Report, the number of people that using public transportation (Bus) in Jakarta were decreasing 21\% from 2002 to 2010 as shown in Figure 3 [6].

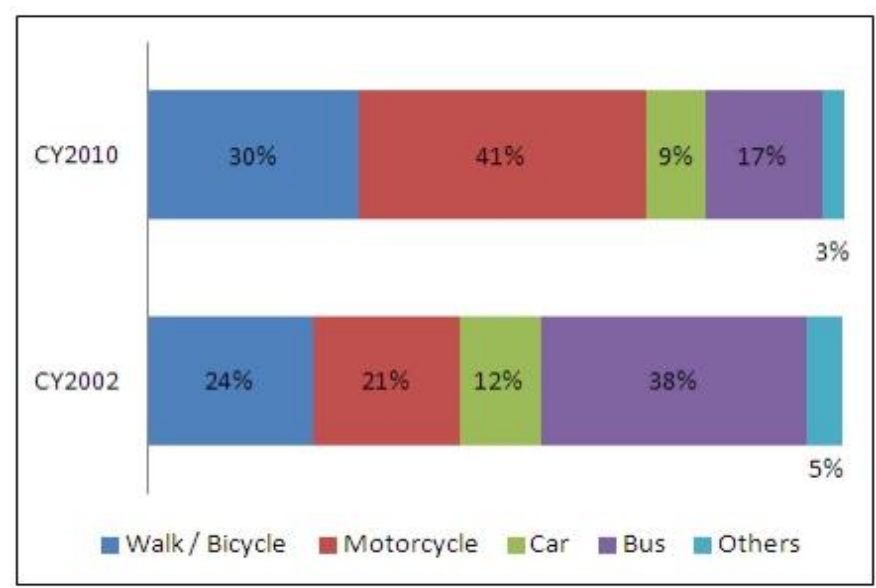

Figure 3. The Change of transportation that people use in Jakarta (2002 and 2010) [6]

\section{Major Challenges in Jakarta Public Transportation}

The reason people wants to use public transportation is to make their life simpler by using public transportation to go anywhere without bring their own vehicle so no need to worry about parking, gasoline, etc. But in Jakarta, the reason why people using the public transportation because their perforce or because they didn't have enough money to get their own vehicle. Based on previous explanation, we can conclude that there are 4 major challenges 
in Jakarta Public Transportation in order to promote people for using public transportation, they are poor facility, poor information, poor security and Society perception.

a. Poor Facility

The facility of the public transportation in Jakarta is still poor, crowded, and uncomfortable. That's why people find it better to use their own vehicle that clean and comfortable rather than using public transportation.

b. Poor Information

One of the reason why people don't want to use public transportation in Jakarta is because they don't have any clear information of public transportation such as time, direction how to go from somewhere, Etc. People prefer to use their own transportation because they can adjust their time to arrive rather than public transportation because they don't know their ETA (Estimated Arrival Time) when the public transportation will arrive and when it will go because there no such information available. The reason is simply because there is no guarantee that people can on time get to their destination.

c. Poor security

One of biggest reason why people don't want to take public transportation in Jakarta is because of poor security. Basically, the security is still questionable whether it save or not. Some public transportation already has officer who take care and ensure the safety of passenger such as Transjakarta and KRL. But for some reason there is still a gap for the bad people who wants to steal something from the passenger and it make the public transportation uncomfortable.

d. Society perception

People who use public transportation in Jakarta is identic to the people who is in lowermiddle class who still living under poverty, or didn't have their own vehicle, etc. So, the people who have "High Level" on their society didn't want to take public

\section{Current Payment for Jakarta Public Transportation System}

Most current payment for public transportation in Jakarta is using cash, next are the list of current payment method for Jakarta public transportation system:

a. Cash

A cash payment refers to when customers pay using physical currency, such as notes and coins [7]. Cash payment is still used to pay public transportation such as angkot, metromini, bus patas, etc.

b. Paper-Based Ticket

Ticket is an old way to use public transportation, however, currently this type of payment is not implemented again for public transportation system in Jakarta. But this paperbased ticket is still used and applied for some other transportation such as flight, inter-city bus, etc.

c. Electronic Wallet

The digital technology, Internet and gadget are products of technology where many experts and engineers in all disciplines involved in the product development [8]. One of the technology product are the electronic wallet. This electronic wallet payment system is similar with the normal cash. What makes different is the cash is already convert into digital money that stored in the account that connected to internet where user can do their transaction online. Example of this electronic wallet is Go-Pay (Gojek App), Grab Pay (Grab App), Smart Card, Etc.

Nevertheless, there are several advantages of the digital currency in association with the electronic payment system such as potential for an increased flexibility, reduced costs for the transactions made within the digital environment, great rapidity regarding the speed of the transactions [9]. The application of electronic wallet is still developing in Indonesia. One of example is application of of NFC (Near Field Communication). NFC system as payment that using electronic wallet have been able to find in several places, such as in Transjakarta that using flazz as the payment, KRL that also use flazz or e-money, and automated vending machine.

Electronic wallets being very useful for frequent online shoppers are commercially available for pocket, palm-sized, handheld, and desktop PCs. They offer a secure, convenient, and portable tool for online shopping. They store personal and financial information such as 
credit cards, passwords, PINs, and much more [10]. Usage of electronic payments, the digital currency has to meet several criteria, thus it has to be [11]:

- Universally accepted

- Electronically transferable

- Divisible

- Impossible to falsify or remove without authorization

- Private (nobody except those who are involved in the transaction, knows value of the transaction)

- Anonymous (nobody can identify the payer)

- Able to also be operated off-line, without needing a previous online verification.

d. Smart Card

Smart card is a technology that using Near Field Communication (NFC) as a media for transferring data such as information, balance, etc. Regarding to the payment system, this smart card is used to store e-money in a card. For thus who don't know, NFC system is a shortrange wireless technology that enables interactivity between electronic devices [12]. There is some available smartcard that already implement in Indonesia such as BNI Tapcash, Mandiri e-money, BCA Flazz, BRI Brizzi, etc. This smartcard can be used as a payment system that already implemented in some public transportation like Transjakarta, Kereta Rel Listrik (KRL). Deploying payment system with NFC system as the replacement of money or ticket based paper, offers important benefits such as significantly reduced revenue collection costs, enhanced customer satisfaction as well as improved services and operational efficiency [13]. This one can implement with the card, or using mobile phone that already support NFC features. No pairing code is necessary to link up and because it uses chips that run on very low amounts of power (or passively, using even less), it's much more power-efficient than other wireless communication types [14]. By applying this NFC, the payment will be paid using one same card. NFC is more secure than RFID and Magitapes [15]. There are three main function of NFC [16]:

1) Card Emulation

Use as a tag for external readers, storing inside all the data, payment cards, loyalty cards, or access keys, but also car keys, identity cards and health cards for public transport.

2) Reader/writer mode

3) Peer-to-peer

Possible to read or write external tags such as smartcards.

Enables to exchange data between devices.

Egger [17], identified ten main functionalities of NFC applicable in tourism. They are: mobile payment, information supply, access authorization, network access, management of loyalty, bonus and membership cards, mobile ticketing, workforce management, identification and location of base services.

NFC nowadays already implemented for some payment for paying public transportation. Some of them already using Smart Card, and now is already develop in some mobile phone to make it more efficient. Technology in the mobile industry has been moving towards the integration of NFC technology in mobile commerce [18]. "NFC technology is considered the mainstream technology of the next generation for the mobile phone products" [19] Along with this statement, there is no doubt that in the future, NFC will take over all of the payment system around the world.

\section{Proposed Smart Integrated Payment System}

Based on 4 major challenges in Jakarta Public Transportation in section 3, then we propose to integrate all payment for Jakarta public transportation by implementing the usage of e-wallet that applied in a system/application inside smartphone by scanning the QR Code (Quick Response Code) as shown in Figure 4, in some public transportation such as Transjakarta, Angkot, Metromini, etc. 


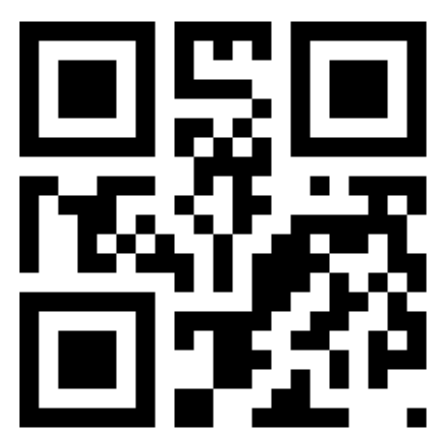

Figure 4. QR code

QR Code is a two-dimensional barcode as seen in Figure 4 which contain alpha-numeric text that usually redirecting user to the referred URL or sites. To interprets the code, need a tool such as camera. QR Codes make a simple creation and easy access to QR readers. QR Code is the innovation to effectively connect the information around locations and object [20]. This QR Code payment system has been proposed in online shopping payment. The QR code will generated the user's necessary data such as user's name, the balance of the money in the internet account, and the payment deducted [21].

We choose to make this because e-wallet is more simple, efficient and minimalize the usage of cash paper in the public. This system is also attracting more people to use the public transportation because this proposed system adopted incentive systems, where someone use public transportation, they will get the point. The more user using public transportation the more benefit they will get.

The usage of e-wallet is very efficient because it needs only smartphone with camera to scan the QR Codes. The user only need to install the application, sign up to get the points or sign in as a guest for temporary use, top up the wallet and its ready to use. To do the payment, the user just simply open the application, scan the QR Code in the public transportation and that's it. Our proposed smart integrated payment Jakarta transportation system, has minimal requirement such as:

a. The account should have nominal balance, where the user should do top up first to fill their account and empty account cannot be used for transportation payment. Moreover, after the empty account scan the QR code, then it will be denied cause that there is no balance.

b. One price for one public transportation's journey, where once the user scans the QR code on public transportation, then their account will be charged with one price, either their do short or long journey in one transportation. This proposed smart integrated payment should only apply for public transportation only such as Transjakarta, KRL, metromini, mikrolet, PATAS and etc. Differ with current online transportation such as GOJEK, UBER and GRAB where the user should define their pickup location and destination and the systems will be decided how much they should pay.

c. The user should download our smart integrated payment application and install it and running in their smartphone.

Furthermore, our proposed smart integrated payment Jakarta transportation system, has some benefit such as:

a. Point System

This system is using incentive system, where someone use public transportation, they will get the point. The point that they have can be redeemed with some promo and discounts. With this feature, it can attract more people to use the public transportation to reduce the traffic jam in Jakarta.

Bulletin of EEI Vol. 6, No. 3, September 2017 : $241-249$ 
b. Redeem System

Redeem means that the point that already collected can be exchanged or redeemed with some promotions and discount offerings through the application.

c. Promo and Discount System

This idea was influenced by online transportation such as GRAB, UBER or GOJEK System where the people can get the promo or discount by such as type like:

1) Getting a discount when top-up balance in such a high amount balance.

2) Getting a discount on specific Events.

d. Business Partnership

Join cooperation with other business such as store, restaurants, school, etc. where users can get discount and promo for their product and spend their point for the transactions. Moreover, business partnership can advertise their product or services as brand awareness. Brand awareness is the ability of a potential buyer to recognize and recall a brand as part of a particular product category [22]. For beginning it will be free for them, and when there is more business partnership request then it will become a new income. the presence of e-marketing as one of the marketing strategies would be appropriate to cover the weaknesses and to solve a number of the marketing problems [23].

e. Smart Application

The application that installed in smartphone, can be used to see the balance inside ewallet, route history, information of public transportation to go somewhere and also the total collected points that user get. Later on, the point can be redeemed to exchange with promotion and discount. There are several features which confirm this application as smart application and they are:

1) E-Wallet Balance

This feature informs about balance remaining in our account.

2) Route History

This feature shows the history of user trip, with such information like when, departure and destination locations, how much, public transportation ID, driver ID and so on.

3) Total Points

Collected points that already get from the trip using public transportation will be displayed through the application.

4) Promo \& Discount Information

The information about promotion and discount that can be redeemed with the points will be showed through application.

5) Public Transportation Information

This shows the information of public transportation. For example, metromini no. 91, This will show the journey route of Metromini no. 91 .

6) Smart Journey Plan

Smart journey plan feature is similar to the application called Trafi (www.trafi.com) which is shows the best route and the best public transportation to reach the destination. This features also tell us the ETA (Estimated time arrival), it more convenient for user to know when they should approach the terminal/bus stop and when they will reach the destination.

Based on previous explanation, then Figure 5 shows, how our proposed systems work:

a. The user need to install the application, register their data and login to the application.

b. The user should top-up the balance of the money to store in the internet account

c. When the user uses the public transportation, they will pay through the printed QR code in the public transportation, by scanning QR code picture.

d. User should connect with internet, open the application, then scan the QR code, so the balance will deduct automatically.

e. The application will automatically connect with the database. 


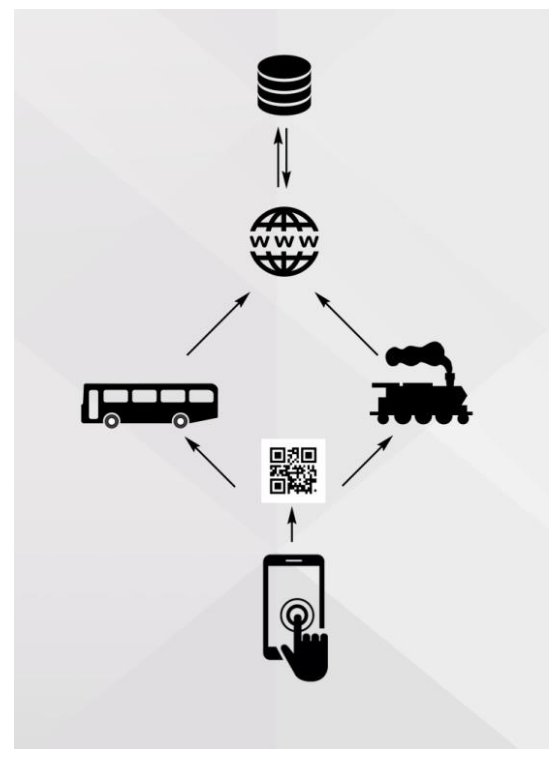

Figure 5. Payment with QR code

\section{Conclusion}

With an integration of payment Jakarta public transportation system with smart integrated payment, we expect to push more people to use public transportation by using incentive system, where we can give a point system when they use public transportation. The point can be redeemed and changed with discount/promo. Moreover, pushing people to use public transportation system rather than using their own transportation to help to reduce amount of traffic jam in Jakarta. The integrated payment system is about using the application and QR code to pay the public transportation. User can simply open the application and scan the QR code printed in the public transportation by top-up the balance on the account.

This proposed system has advantages and interesting features which is efficient, nowadays people like to bring their smartphone anywhere and anytime, this e-wallet system is efficient because user just need to open their smartphone to open the application, scan the QR code, and the money stored will automatically deducted. This system also using incentive system, so the user that use the application can get advantages with getting points after paying the public transportation, it can directly redeem with the discount available.

User also can get the promo and discount to pay the public transportation only by entering the promo code. The business that do partnership with us also get the benefit to get free advertise from our system. By installing our application, the user can easily go travelling with only bring their smartphone, they can pay through their smartphone and get the information about public transportation easily. To know more information, we also provide smart application that have many features such as e-wallet balance, route history, total points, promo and discount information, public transportation information, and smart journey plan.

\section{References}

[1] Jakarta, http://www.indonesia.travel/en/destination/area/jakarta. [Accessed: 01-Jun-2017].

[2] Transportasi

$$
\text { Umum lbukota. }
$$

[Online].Available:https://maskomuter.wordpress.com/2011/04/03/transportasi-umumibukota.[Accessed: 06-jun-2017]

[3] TD Wicaksono. 5 Faktor Mengapa Warga Ibukota Memilih Kendaraan Pribadi daripada Kendaraan Umum. tegarberdiri, 20-Feb-2015. [Online]. Available: https://tegarberdiri.wordpress.com/2015/02/20/5-faktor-mengapa-warga-ibukota-memilih-kendaraanpribadi-daripada-kendaraan-umum/. [Accessed: 09-Jun-2017].

[4] HA Raharjo. The Alternative Solution for Traffic Problem in Jakarta-Indonesia. International Journal of Business and Management Studies. 2012; 1(2): 315-320. 
[5] A Wismadi, J Soemardjito, H Sutomo. Transport Situation in Jakarta. 2013, in Kutani, I. (ed.). Study on energy efficiency improvement in the transport sector through transport improvement and smart community development in the urban area. ERIA Research Project Report, pp.29-58, 2012.

[6] The Coordinating Ministry of Economic Affairs the Republic of Indonesia. JABODETABEK Urban Transportation Policy Integration Project in the Republic of Indonesia. 2017.

[7] Department of Industry, Innovation and Science. Cash payments. Jun-2016. [Online].Available: https://www.business.gov.au/info/run/finance-and-accounting/accounting/payments-andinvoicing/cash-payments. [Accessed: 06-Jun-2017].

[8] B Soewito, SM Isa. Digital Technology: the Effect on Connected World to Computer Ethic and Family. CommIT Journal. 2015; 9(1): 23-28,

[9] O Dospinescu. E-Wallet. A New Technical Approach. Economica. 2012; 8(5): 84-94.

[10] A. Upadayaya. Electronic Commerce and E-wallet. International Journal of Recent Research and Review. Mar 2012; 1: 37-41.

[11] A Shalodkar, K Money, M Shirbate. Electronic Wallet. International Research Journal of Engineering and Technology (IRJET). Dec. 2015; 2(09): 975-977.

[12] NFC Forum, Inc. NFC in Public Transport. 2011 [Online].Available: nfc-forum.org/wpcontent/uploads/2013/12/NFC-in-Public-Transport.pdf. [Accessed:06-Jun-2017].

[13] A Rupp, F Baldimtsi, G Hinterwalder, C Paar. Cryptographic Theory Meets Practice: Efficient and Privacy-Preserving Payments for Public Transport. ACM Transactions on Information and System Security (TISSEC). 2015; 17(3).

[14] C Faulkner. What is NFC? Everything you need to know. 2017. [Online]. Available:http://www.techradar.com/news/what-is-nfc. [Accessed: 06-Jun-2017].

[15] F Michahelles, F Thiesse, A Schmidt, JR Williams. Pervasive RFID and Near Field Communication Technology. IEEE Pervasive Computing. 2007; 6(3): 94-96.

[16] O Falke, E Rukzio, U Dietz, P Holleis, A Schmidt. Mobile Services for Near Field Communication. Tech. Rep., University of Munich, Department of Computer Science, Media Informatics Group: $\begin{array}{lll}\text { Munich, } & \text { Germany, [Online]. }\end{array}$ Available:http://www.mmi.ifi.Imu.de/pubdb/publications/pub/falke2007mobileServicesTR/falke2007mo bile ServicesTR.pdf. [Accessed: 07-Jun-2017].

[17] R Egger. The impact of Near Field Communication on Tourism. J. Hosp. Tour. Technol. 2013; 4:119$133,$.

[18] H Du. NFC Technology: Today and Tomorrow. International Journal of Future Computer and Communication. 2013; 2(4): 351-354.

[19] SH Wu, C Yang. A Study on Designing the New near Field Communication Technology-NFC-micro SD Technology. Inf. Technol. J. 2013; 13: 1455-1458.

[20] Educase Learning Initiative. 7 Things you should Know about QR Codes. 2009.[Online].Available: https://net.educause.edu/ir/library/pdf/ELI7046.pdf. [Accessed: 09-Jun-2017].

[21] A Surekha, PM Rubesh Anand, I Indu. E-Payment Transactions Using Encrypted QR Codes. International Journal of Applied Engineering Research. 2015; 10(77): 461.

[22] HB Tritama, RE Tarigan. The Effect of Social Media to the Brand Awareness of a Product of a Company. CommIT Journal. 2016; 10(1): 9-14.

[23] RE Tarigan, KS Dewi. Web-based implementation of e-marketing to support product marketing of chemical manufacturing company. CommlT (Communication \& Information Technology) Journal. 2015; 9(2): 73-82.

[24] F Ferdianti, Y Triyuswoyo, DA Rahayu. Utilization of Near Field Communication Technology for Loyalty Management. TELKOMNIKA (Telecommunication Computing Electronics and Control). 2013; 11(3): 617-624.

[25] E Bonner, JO Raw, K Curran. Implementing the Payment Card Industry (PCI) Data Security Standard (DSS). TELKOMNIKA (Telecommunication Computing Electronics and Control). 2011; 9(2): 365-376,.

[26] Z Yuan, MY Feng. Design of Intelligent Transportation System Based on the Technology of Information and Communication Engineering. TELKOMNIKA (Telecommunication Computing Electronics and Control). 2016; 14(2A): 180-188,.

[27] L Fanani, A Basuki, D Liang. Bus Arrival Prediction-to Ensure Users not to Miss the Bus. International Journal of Electrical and Computer Engineering (IJECE). 2015; 5(2): 333-339.

[28] D.N.A. Zaidel, N. Seman, M.R.M. Sharip, D.A.A. Mat and N.A.A. Mohtadzar. 5G Coupler Design for Intelligent Transportation System (ITS) Application. International Journal of Electrical and Computer Engineering (IJECE). 2017; 7(2): 899-904. 